\title{
UNSOLICITED MERCHANDISE: STATE AND FEDERAL REMEDIES FOR A CONSUMER PROBLEM
}

The practice of sending merchandise as an offer of sale without an order or solicitation has long plagued the consumer. ${ }^{1}$ Gifts of unsolicited goods provide effective advertising since consumers welcome a free opportunity to try a new product, ${ }^{2}$ but when unsolicited merchandise ${ }^{3}$ is sent as an offer of sale, subsequent attempts to collect payment present difficult consumer problems. ${ }^{4}$ The problems have prompted action by several state legislatures, ${ }^{5}$ Congress, ${ }^{6}$ and the Federal Trade Commission ${ }^{7}$ attempting to regulate or eliminate this sales technique. Such efforts have radically changed

1. See generally FTC Consumer Bulletin No. 2, "Unordered Merchandise-Shipper's Obligations and Consumer's Rights" (June 25, 1968), 2 TradE REg. REP. II 7559.75 (1969). Although no statistics are available, the scope of the problem is indicated by some of the findings of fact made by the hearing examiner in Joseph L. Portwood, No. 8681 (F.T.C. Jan. 19, 1968), final order issued, [1967-70 Transfer Binder] TRADE REG. REP. I 18,176 (FTC 1968), affd. 418 F.2d 419 (10th Cir. 1969). The defendant, a professional stamp dcaler, estimated that 5,000 dealers in the United Statcs mailed unsolicited stamps.

2. If the free goods are razor blades or drugs and are appropriated by children before reaching the intended recipient, a serious health hazard may exist. A bill, H.R. 3954, 90th Cong., Ist Sess. (1967), was once introduced to prohibit the unsolicited mailiug of such products except to physicians, dentists, and barbers. Hearings were held, but the bill was not reported out of committee. See Hearings on H.R. 3954 Before the Subcomm. on Postal Operations of the House Comm. on the Post Office and Civil Serv., 90th Cong., 1st Sess. (1967).

3. "Unsolicited merchandise" might include any goods, periodieals, or services sent or performed without a specific order or authorization from the recipient. In this comment, however, unless otherwise indieated, "unsolicited merchandise" and "unsolicited goods" will be defined more narrowly to include goods, periodicals, or services sent without an order or authorization as a means of offering the goods for sale. Thus, the terms will not include goods ordered but sent to the wrong person or goods sent after an order was cancelled, e.g., B.F. Goodrich Rubber Co. v. Parchelsky Bros., 183 N.Y.S. 30 (Sup. Ct. 1920); Gulf C. \& S.F.Ry.v. Wortham, 154 S.W. 1071 (Tex. Civ. App. 1913); the wrong goods sent to fill an order, see UNIFORM COMMERCIAL CODE $\S \S 2-602(2), 2-603,2-604$ [hereinafter cited as UCC] (buyer's dutics as to rightfully rejected goods); or goods sent by a third party who fills an order placed by the recipient. E.g., Barnes v. Shoemaker, 112 Ind. 512, 14 N.E. 367 (1887).

4. Sce Objections to Unsolicited Merchandise infra, pages 992 to 993 . Although businesses and institutions also receive unsolicited merchandise, the practice is predominantly a consumer problem. Still, the National Better Business Bureau has joined consumer groups in expressing concern. See, e.g., 1968 Consumer RePORTs 575; National Better Business Bureau, Inc., Service Bulletin No. 398 (August, 1968).

5. See notes 55 to 84 infra and accompanying text.

6. Postal Reorganization Act, Pub. L. No.91-375 (August 12, 1970). See notes 139 to 147 infra and accompanying text.

7. Sce notes 85 to 124 infra and accompanying text. 
the common law concerning unsolicited goods ${ }^{8}$ and may seriously limit their utility. This comment will analyze the nature and interaction of the common law, state statutes, FTC efforts, and postal restrictions, focusing on a recipient's obligation to pay for, return, or protect unsolicited goods.

\section{Objections to UnSolicited Merchandise}

Objections to unsolicited merchandise as a sales technique emphasize the inconvenience to the recipient, the deceptive nature of the practice, and its anti-competitive effects. For the recipient, unsolicited goods are a nuisance and frequently cause the incurrence of expenses. They must be refused, returned, disposed of, stored, or paid for, and the recipient is often compelled to communicate with the sender. Most of these responses require time and the expenditure of money.

More serious, however, are the deceptive aspects of this sales method. Demands for payment accompanying or following the goods usually state explicitly, or at least imply, that the recipient is obligated to pay for ${ }^{9}$ or return the goods. ${ }^{10}$ Moreover, sellers sometimes use the names of non-existent collection agencies or credit rating bureaus in demanding payment, ${ }^{11}$ threatening to ruin the recipient's credit reputation if he fails to pay, ${ }^{12}$ and accusing him of having stolen the goods if he holds them. ${ }^{13}$

8. See notes 17 to 54 infra and accompanying text.

9. In Joseph L. Portwood, [1967-70 Transfer Binder] Trade REg. Rep. If 18,176 at 20,590 (FTC 1968), the FTC found that "deception inheres in the very act of attempting to persuade respondents' mailees to purchase the merchandise." The deception began with the approval invoice sent with the goods which had the notation "please return this invoice with your payment" which, according to the Commission, implied an obligation to pay. Id. at 20,588. See also Linden v. United States, 254 F.2d 560 (4th Cir. 1958); Independent Directory Corp. v. FTC, 188 F.2d 468 (2d Cir. 1951). Apart from specific deceptive practices, the unsolicited sales technique at least forees the recipient to see the goods. In Portwood the defendant justified sending goods to recipients after receiving requests not to send more merchandise on the ground that the recipients really did not mean what they said and that previous experience had shown that they would make additional purchases if confronted with more goods. Joseph L. Portwood, No. 8681 at 31-32 (F.T.C. Jan. 19, 1968) (Hearing Examiner opinion).

10. If the goods are returned to the sender, a subsequent deception will occur if they are resold as new. The FTC has required disclosure of the fact that merchandise previously has been sent unordered or on a trial basis and prohibited the resale of such goods as a new product. FTC Noticc, 34 Fed. Reg. 176 (1969).

11. David Tcitelbaum, 49 F.T.C. 745 (1953).

12. House of Plate, Inc., 47 F.T.C. 1411 (1951).

13. Joseph L. Portwood, [1967-70 Transfer Binder] Trade REg. ReP. If 18,176 at 20,586 (FTC 1968). 
Since a competitive market is dependent upon access to information and freedom of choice, ${ }^{14}$ such deception also hinders competition by discouraging comparative shopping and emphasizing coercion and consumer ignorance. Because payment is made for many unsolicited goods to satisfy an ostensible legal obligation or to avoid harassment, ${ }^{15}$ the practice produces sales of unwanted merchandise which causes the expenditure of resources on goods unlikely to be fully utilized. Moreover, the sale of unwanted merchandise may artificially sustain a failing business. ${ }^{16}$

\section{Common Law Obligations}

An understanding of the common law of unsolicited goods is essential to determine where deception occurs in order to evaluate remedies for eliminating unsolicited sales or at least minimize their worst characteristics. Most unsolicited merchandise cases have involved goods sent to one merchant by another and have resulted in opinions phrased in the terminology of commercial obligations. ${ }^{17}$ While no inherent legal difference exists between the liability of the individual consumer and a merchant for unsolicited goods, a merchant's obligations are more likely to be affected by a usage of trade, prior dealing, or course of performance..$^{18}$ Moreover, a merchant is likely to be aware that a sale is intended, a factor that may affect the recipient's liability. ${ }^{19}$ Even though the merchant cases may not always be of precedential value for determining an individual consumer's legal obligations, they remain significant because of the dearth of opinions involving consumers.

14. See E. Chamberlain, The Theory of Monopolistic Competimon 3-29 (1960); C. Edwards, Maintaining Competition 9-11 (1949); C. Kaysen \& D. Turner, Antttrust Policy 7-23 (1959). See generally P. AREEDA, ANTITRUSt ANALYSIS 5-17 (1967).

15. See Joseph L. Portwood, [1967-70 Transfer Binder] TRADE REG. REP. I 18,176 at 20,588 .

16. The defendant in Portwood implied that he could not stay in business without the deception implicit in sending unsolicited goods. Id. at 20,591 .

17. "Upon the authorities it is plain; that it is the clear duty of one merchant, who receives goods from another with a bill showing they are sent as a sale, to notify the sender, that he will not receive the goods or become liable for them, unless they are detained for the purpose of examining the quantity and quality, which must be done in a reasonable time according to the circumstances of the case." Bartholomae \& Co. v. Paull, 18 W. Va. 771, 780 (1881). See also Johnson v. Guttegno, 267 S.W. 740 (Tex. Civ. App. 1924).

18. For cases rccognizing course of performance as a factor affecting a merchant's liability for unsolicited goods, see Excelsior Stove \& Mfg. Co.v. Venturelli, 290 Ill. App. 502, 8 N.E. 702 (1937); Hobbs v. Massasoit Whip Co., 158 Mass. 194, 33 N.E. 495 (1893). Cf. UCC \$§ 1205(1) \& (2), 2-208, 2-104(1) \& (3) \& Comment 2.

19. See generally note 38 infra. 
In determining a recipient's liability for unsolicited goods, courts generally have not made distinctions based on the character of the merchandise. ${ }^{20}$ Periodicals, however, are an exception in part because of the almost instantaneous benefit derived from their receipt. ${ }^{21}$ But the recipient of an unsolicited periodical or a periodical which continues to be sent after the subscription expires can avoid liability by refusing delivery or by immediately returning the unopened periodical to the publisher. ${ }^{22}$ If the recipient accepts and reads the periodical, he must pay the subscription price even though he notifies the publisher that he does not desire to subscribe..$^{23}$ Where a recipient holds a periodical without reading it and notifies the publisher, liability may still exist because of the minimal value of out-of-date periodicals and the ease with which they can be refused..$^{24}$

One may avoid obligation for any type of unsolicited goods by refusing delivery, but acceptance does not necessarily obligate the recipient to pay for or return the goods. Usually the recipient will be required to pay only if he uses, ${ }^{25}$ displays,${ }^{26}$ gives away, ${ }^{27}$ destroys, ${ }^{23}$ or

20. Cf. Austin v. Burge, 156 Mo. App. 286, 290-91, 137 S.w. 618, 619 (1911). "The preparation and publication of a newspaper involves much mental and physical labor, as well as outlay of money. One who accepts the paper, by continuously taking it from the post office, receives a benefit and pleasure arising from such labor . . . and by such act he must be held liable for the subscription price."

21. See Ferrous Prod. Co.v. GulrStates Trading Co., 323 S.W.2d 292 (Tex. Civ. App. 1959), aff d, 160 Tex. 399, 332 S.W.2d 310 (1960); Thompson v. Douglass, 35 W. Va. 337, 13 S.E. $1015(1891)$.

22. Ward v. Powell, 3 Harr. 379 (Del. 1841). Under postal regulations an addressee may refuse to accept mail when offered for delivery or, after delivery (except in the cases of registered, insured, certified, or COD mail), may mark it "refused" and return it unopened to the post office. If the mail is opened, the recipient must pay return postage. See note 125 infra and accompanying text.

23. Ward v. Powell, 3 Harr. 379 (Del. 1841); Austin v. Burge, 156 Mo. App. 286, 137 S.W. 618 (1911); Fogg v. Portsmouth Atheneum, 44 N.H. 115 (1862). See also Prospect News Printing Co. v. Swindle, 15 S.W.2d 922 (Mo. Ct. App. 1929); Goodland v. LeClair, 78 Wisc. 176, 47 N.W. 268 (1890); Wcatherby v. Banham, 172 Eng. Rep. 950 (K.B. 1832).

24. See generally Austin v. Burge, 156 Mo. App. 286, 137 S.W. 618 (1911); Goodland v. LeClair, 78 Wisc. 176, 47 N.W. 268 (1890). But see Realty Records Co.v. Pierson, 116 N.Y.S. 547 (Sup. Ct. 1909); 1 A. CorBin, Contracts $\$ 75$ at 319 (1963) [hereinafter cited as CorBIN]

A variation of the unsolicited periodieal problem occurs when a periodical ceases publication and subscribers are offered a choice of other periodicals as a substitute. To eliminate coercing subscribers to accept an unwanted periodical, the FTC has directed that a publisher must also offer subscribers the option of a eash refund. FTC News Release, March 18, 1969, BNA ANTITRUST \& TRADE REg. ReP. No. 402, at A-8 (1969).

25. Ferrous Prod. Co. v. Gulf States Trading Co., 323 S.W.2d 292 (Tex. Civ. App. 1959); Johnson v. Gattegno, 267 S.W. 740 (Tex. Civ. App. 1924). But if entitled to compensation he may use the goods as long as such goods are no more than reasonable compensation, Alvord $v$. Davenport, 43 Vt. 30 (1870). Sce notes 49-54 supra and aecompanying text. 
otherwise handles the goods in a manner inconsistent with the sender's ownership..$^{29}$ The recipient who does not deal. with the goods in any manner need not return them to avoid an obligation to pay, although he must hold the goods for the sender. ${ }^{30}$ If the recipient decides to hold but not accept the goods, he is generally not required to notify the sender. ${ }^{31}$ Moreover, the sender cannot impose such a duty by informing the recipient that silence will be interpreted as acceptance. ${ }^{32}$ However, where a reasonable man would have spoken out, the sender may be justified in concluding that the recipient has accepted the goods or services on the offered terms-if there is a trade usage, ${ }^{33}$ prior dealing ${ }^{34}$ or other communication with the sender,,$^{35}$ or when services are performed under circumstances where the recipient could casily communicate with the sender. ${ }^{36}$

26. Colonna v. Eisman, 98 Okla. 107, 224 P. 181 (1924); cf. UCC § 2-326 (sale on approval and sale or return).

27. Louisville Tin \& Stove Co. v. Lay, 251 Ky. 584, 65 S.W.2d 1002 (1933); Thompson v. Douglass, 35 W. Va. 337,13 S.E. 1015 (1891); RESTATEMENT OF CoNTRACTS $\$ 72(2)$, illus. 6 (1932) [hereinafter cited as RESTATEMENT].

28. Hobbs v. Massasoit Whip Co., I58 Mass. 194, 33 N.E. 495 (1893); cf. RESTATEMENT $\S$ 72(2), RestatemeNt (SECOND) OF Contracts § 72(2), Comment $e$ (tent. draft No. 1, 1964) [hereinafter cited as RESTATEMENT (SECOND)].

29. Marr v. Marr, 319 S.W.2d 920 (Mo. Ct. App. 1959); Austin v. Burge, 156 Mo. App. 286, 137 S.W. 618 (1911); Restatement \& 72(2); Restatement (SECOND) \& 72(2); I S. Williston, Contracts $\S \S 71$ at 233-34, 910 at 333 (3d ed. 1957) [hereinafter cited as WiLLISTON].

30. Hedden v. Roberts, 134 Mass. 38 (1883).

31. Excelsior Stove Mig. Co. v.Venturelli, 290 Ill. App. 502, 8 N.E. 702 (1937) (dicta); 1 CoRBIN $\S \S 72$ at 306,73 at 310 . ReSTATEMENT $\S 72(2)$, illus. 7 . But see Bartholomae \& Co.v. Paull, 18 W. Va. 771, 779 (1881); 1 WILLISTON §91D at 332. See generally, Acceptance by Silence: A Critique, 7 Duke BAR Assoc. J. 87 (1937).

32. "He cannot force the offeree to take his pen in hand, or to spend a two cent stamp, or to open his mouth, under penalty of being bound by a contract if he does not." 1 CoRBIN $\S 73$ at 310. See also Albrecht Chem. Co. v. Anderson Trading Corp., 298 N.Y. 437, 84 N.E.2d 625 (1949). But cf.T.C. May Co. v. Menzies Shoe Co., 184 N.C. 150, 113 S.E. 593 (1922).

33. Painter v. Ritchey, 43 Mo. App. 111 (1890); 1 CoRbiN $\S 75$ at 322; cf. T.C. May Co.v. Menzies Shoe Co., 184 N.C. 150, 113 S.E. 593 (1922); Cole-Mcl ntyre-Norfleet Co. v. Holloway, 141 Tenn. 679, 214 S.W. 817 (1919); Hendrickson v. International Harvester Co. $100 \mathrm{Vt.} 161,135$ A.702 (1927); UCC $\S 1-205$ (2) (definition of trade usage).

34. E.g., Whecler v. Klaholt, 178 Mass. 141, 59 N.E. 756 (1901); Hobbs v. Massasoit Whip Co., 158 Mass. 194, 33 N.E. 495 (1893); Restatement $\$ 72(1)(c)$; Restatement (SECOND) $\S 72(1)(c) ; c f$. UCC $\& 1-205(1)$ (course of dealing). Such prior dealings are frequent in the renewal of insuance contracts. E.g., Eicks v. Fidelity \& Cas. Co., 300 Mo. 279, 253 S.W. 1029 (1923); National Union Fire Ins. Co. v. Ehrlich, 122 Misc. 682, 203 N.Y.S. 434 (App. Div. 1924); Restatement (SeCOND) § 72, illus. 6, at 294; G. Couch, Cyclopedia of Insurance LAW § 12:15 (2d ed. 1959).

35. E.g., Ammons v. Wilson \& Co., 176 Miss. 645, 170 So. 227 (1936); Indiana Mfg. Co. v. Hayes, 155 Pa. 160, 26 A. 6 (1893).

36. Day v. Caton, 119 Mass. 513 (1876); Watkins v. Trustees of Richmond College, 41 Mo. 
Since recipient liability requires knowledge that the sender expects to be paid, ${ }^{37}$ arguably a recipient has no obligations if he receives the goods or services under circumstances reasonably inducing his honest belief that they were intended as a gift and uses them before he learns otherwise.$^{38}$ Such a result can be justified on the ground that the sender incurred this risk by choosing the sales method. However, a court might hold the recipient liable for the amount enriched on a quasi-contract theory. ${ }^{39}$

Several circumstances complicate an assessment of the rights and duties of the recipient: a sender providing or guaranteeing return postage; ${ }^{40}$ a third party ordering goods for the recipient; ${ }^{11}$ the recipient having requested the sender not to send any further unordered goods; ${ }^{42}$ or the seller delivering goods in excess of those ordered by the recipient. ${ }^{43}$ When such factors are combined with the variables of prior dealing, use or storage of the goods, and notice or lack of notice to the sender, the recipient's obligations are likely to be unclear.

If the recipient deals with the unsolicited goods, liability may be grounded in either tort or contract. ${ }^{44}$ The sender can secure the return

302, 309 (1867); Painter v. Ritchey, 43 Mo. App. 111 (1890); Jones v. Brisbin, 41 Wash. 2d 167, 247 P.2d 891 (1952); 1 CoRB1N $\S 75$ at 321; 1 WiLLISTON $\S 91 D$ at 332; $c$. Hartnctt v. Christopher, 61 Mo. App. 64 (1895); Hicmenez v. Goerger, 51 Mo. App. 586 (1892).

37. See Louisville Tin \& Stove Co. v. Lay, 251 Ky. 584, 586, 65 S.W.2d 1002, 1003 (1933); Jones v. Brisbin, 41 Wash. 2d 167, 172 P.2d 891,894 (1952); Bartholomae \& Co. v. Paull, 18 W. Va. 771,780 (1881); RESTATEMENT $\S 72(2)$ (a); 1 WILLISTON $\S 91 \mathrm{D}$ at 332.

38. E.g., Morris v. Bruce, 98 Ga. App. 821, 107 S.E.2d 262 (1959). Where the recipient's honest belicf is not supported by the circumstances of his receiving the goods or services, an implied agreement to pay for their value will be assumed. Austin v. Burge, 156 Mo. App 286, 137 S.W. 618 (1911).

39. See, e.g., Hill v. Waxberg, 237 F.2d 936, 939 (9th Cir. 1956); Matarese v. MooreMcCormack Lines, Inc., 158 F.2d 631,634 (2d Cir. 1946).

40. See RESTATEMENT $\S 72(2)$ illus. 6, which suggests that a promise iu r icturn postage would obligate the recipient to return the goods.

41. See, e.g., Barnes v. Shoemaker, 112 Ind. 512, 14 N.E. 367 (1887); Sture ant v. Wallack, 141 Mass. 119, 4 N.E. 615 (1886); Goodrich v. Rust, 143 Mo. App. 714, 128 S.W. 847 (1910). In Sturevant the order was placed by a contractor doing work for the recipicnt. The recipicnt was held liable for the contract price on the ground that he accepted the goods and should have protested the sender's bill if he did not want them.

Orders are sometimes placed by third parties maliciously or as a prank by using order blanks found in advertising materials. Sellers usually send the goods without confirming the order or requiring prepayment. For the FTC's handling of such cases, see note 79 infra.

42. See Portwood v. FTC, 418 F.2d 419, 421 (10th Cir. 1969).

43. See Dorfman v. FTC, 144 F.2d 737 (8th Cir. 1944).

44. Ferrous Prod. Co. v. Gulf States Trading Co., 323 S.W.2d 292, 296 (Tex. Civ. App. 1959); Restatement § 72(2); RestatemENT (SECoND) § 72(2). The option in selecting the theory of liability is the sender's, and the recipient cannot avoid contractual obligations by asserting he is a tortfeasor rather than a promisor. Id. $\S 72(2)$, Comment $e$. 
of the goods through a bill in equity or obtain damages equal to the value of the goods on a theory of wrongful conversion..$^{45} \mathrm{~A}$ contract action can be maintained on either an implied contract or quasicontract theory, ${ }^{46}$ with damages ordinarily measured by the seller's price in either case. ${ }^{47}$ If the seller's terms were manifestly unreasonable, the amount of recovery will equal the market value of the goods. ${ }^{48}$

By holding unsolicited goods for the seller, thereby avoiding any contractual obligations or tort liability, the recipient becomes a gratuitous, involuntary bailee. ${ }^{49}$ As such, he need not take affirmative steps to care for the goods ${ }^{50}$ and will be liable only for gross negligence. ${ }^{51}$ Since the bailor-sender voluntarily placed the goods with the bailee-recipient, he can be presumed to have consented to pay the recipient's storage expenses.52 Immediate notice by the recipient of intent to charge the sender would increase his chances of recovery but might also increase the standard of care to which he is subject..$^{53}$ The

45. Restatement of Restitution $\$ 128$, Comments $k$ \& $l$, 151 (1936); $c f$. B.F. Goodrich Rubber Co.v. Parshelsky Bros., 183 N.Y.S. 30 (Sup. Ct. 1920).

For the measure of damages if the recipient converts the goods before he realizes payment is expected see RESTATEMENT OF RESTITUTION § 154 (1936).

46. Louisville Tin \& Stove Co.v. Lay, 251 Ky. 584,65 S.W.2d 1002 (1933); Jones v. Brisbin, 41 Wash. 2d 167, 247 P.2d 891 (1952); RESTATEMENT $\S 72(2) ; 1$ Williston $\S 71$ at 233-34. See note 39 infra.

47. Restatement (Second) § 72(2), Comment $e$ at 295.

48. Id.

49. 9 WILLISTON $\S 1038 \mathrm{~A}$. Since the sender does not intend to abandon the goods or make them a gift, the only alternative to bailment is custody. The distinction depends upon whether the sender intended to depart with the right of dominion over the goods. See R. Brown, Personal ?ROPERTY $\S 76$ (2d ed. 1955) [hereinafter cited as Brown]. Because the goods are being offered for sale, the recipient can effect a change in title by accepting the offer. Thus, the sender appears to be granting the recipient the right of dominion, and a bailment exists. See Laidlaw, Principles of Bailment, 16 CoRNELL L.Q. 286, 304-06 (1931); 22 ColuM. L. REV. 354 (1922). Moreover, the recipient has received physical control of the goods without volunteering to care for them, has demonstrated possessory intent by not returning or disposing of the goods, and probably will not be compensated for his efforts. BRown $\S \S 74,75$.

50. Brown § 91 .

51. Bain v. Culbert, 209 Ala. 312, 96 So. 228 (1923); Hargis v. Spencer, 254 Ky. 297, 71 S.W.2d 666 (1934); Altman v. Aronson, 23I Mass. 588, 121 N.E. 505 (1919); Smith v. Nashua \& L.R.R., 27 N.H. 86 (1853); Brown $\$ \S 83,91$. But see Cowen v. Pressprich, 117 Misc. 663, 669, 192 N.Y.S.2d 245 (Sup. Ct.), rev'd, 202 App. Div. 796, 194 N.Y.S. 926 (1922). See also Preston v. Prather, 137 U.S. 604 (1891); Foster v. Essen Bank, 17 Mass. 479, 498 (1821).

52. Leavy v. Kinsella, 39 Conn .50 (1872); Preston v. Neale, 12 Gray 222 (Mass. 1858); Grice v. Berkner, 148 Minn. 64, 180 N.W. 923 (1921); Moline, Milburn \& Stoddard Co.v. Nevillce, 52 Neb. 574, 2 N.W. 854 (1897); Christopher v. Jerdec, 152 Wis. 367, 139 N.W. 1132 (1913); BRown $\S 91$ at 413-14.

53. Smith v. Nashua \& L.R.R., 27 N.H. 86 (1853). 
bailment will continue until the sender reclaims the goods, donates them to the recipient, or ab andons them. Both gift and abandonment normally require some inference of the sender's intent. Since time is generally the only basis for this inference, termination of the bailment by abandonment is more likely than termination by gift..$^{54}$

Unfortunately, the average recipient of unsolicited merchandise knows nothing of the legal notions of abandonment or bailment and cares little that he might be able to sue for storage expenses. The practice might disappear if consumers knew and understood the law concerning unsolicited goods since the cost of holding the goods ordinarily is minimal and senders usually could not afford to collect them. Although some people undoubtedly pay for unsolicited goods only because they want them, complaints suggest that many of the sales result from a supposed legal obligation to pay. Consumer ignorance assures that the practice thrives.

\section{STATE REMEdies}

A number of state legislatures have attempted to regulate unsolicited goods by enacting statutes reversing prior case law. The first statutes enacted in the 1800's sought to protect recipients from liability. An 1851 Florida statute provides that "[n]o person shall be liable to pay for any newspaper, periodical or other like matter, unless he shall subscribe for or order the same in writing." 55 Other statutes deemed unordered periodicals to be gifts ${ }^{58}$ or explicitly protected periodical subscribers from liability for continued delivery after expiration of their subscriptions. ${ }^{57}$ The Virginia statute, the first applicable to all unordered goods, ${ }^{53}$ precludes suit for the value or recovery of goods sent by mail unless expressly or impliedly ordered or appropriated to the recipient's use. ${ }^{59}$ This statute clarifies the legal

54. For cases discussing grounds for inferring an intention to abandon, see Eads v. Brazelton, 22 Ark. 499 (1861); Row v. Home Sav. Bank, 306 Mass. 522, 29 N.E.2d 552 (1940); Whitman v. Muskegon Log Lifting Co., 152 Mich. 645, 116 N.W. 614 (1908); Fidelity-Phil. Trust Co. v. Lehigh Valley Coal Co., 294 Pa. 47, 143 A. 474 (1928); cf. 33 lowa L. Rev. 155 (1947). The time required for the presumption of abandonment will probably vary with the value of the goods.

55. Fla. Stat. ANN. § 725.03 (1944).

56. E.g., ORE. Rev. Stat. § 98.450 (1969); Wash. Rev. Code § 19.56 .020 (1967).

57. See Neb. Rev. Stat. § 63-101 (1943).

58. VA. CODE ANN. § 11-2.1 (1964 repl. vol.).

59. No suit shall be maintained, . . . to recover any goods, property or thing, or the value thereof which has been sent to any person by mail, unless such goods, property or thing has been impliedly or expressly ordered by the person to whom the same has been sent and received or unless it be proved that such person has appropriated such goods, property or thing to his own use. Id. 
rights and duties of the recipient, allowing an informed consumer to dispose of the goods or give them away without liability, but does little to eliminate a sales technique aimed at the ignorant and easily intimidated recipient.

In 1967 Cahfornia enacted a statute prohibiting the solicitation of money for unordered goods or future services by sending a statement or invoice unless it clearly stated that the recipient was only obligated to pay if he accepted the offer. ${ }^{60}$ The act also provides treble damages for persons injured by violations. ${ }^{61}$ While such a statute might eliminate one form of misleading solicitation, its value is limited since there are many other ways of deceiving a recipient as to his supposed legal obligations..$^{22}$

The recent trend has been toward comprehensive gift statutes allowing the recipient to refuse, use, or dispose of the goods without any resulting obligation. ${ }^{63}$ The Washington statute, ${ }^{64}$ which applies only to mailed goods, deems unsolicitcd goods to be gifts and declares that in any suit for the price or return of the goods it shall be a complete defense that they were voluntarily sent and not ordered or requested by the recipient. Maryland's statute offers a similar defense. ${ }^{65}$ Other states have permitted the recipient to treat the goods as "unconditional gifts . . . unless otherwise agreed," possible argument that acceptance evidenced agreement to the sender's terms.

60. Cal. Civil Code $\S 1716$ (West Supp. 1970).

61. Id.

62. California subsequently strengthened its position against such unsolicited merchandise. Id. $\S 15845$. See note 69 infra and accompanying text.

63. See ARK. Stat. Ann. § 85-2-606.1 (Supp. 1969); Fla. Stat. Ann. § 570.284 (Supp. 1970-71); Idaho Code ANN. § 28-2-329 (Supp. 1969); lll. Rev. Stat. ch. 121 1/2, §351 (Supp. 1970); lowa Code ANn. § 556A.1 (Supp. 1970); Me. Rev. Stat. AnN. § 33-1101 (Supp. 1970-71); Mo. Ann. Stat. ` 407.200 (Supp. 1969-70); Wash. Rev. Code ANN. \& 19.56.020 (Supp. 1969); PA. Stats. ANN. § 2001 (Supp. 1970). Such gift statutes are typically worded as follows:

Unless otherwise agreed, where unsolicited goods are delivered to a person, he has a right to refuse to accept delivery of the goods and is not bound to return such goods to the sender. If such unsolicited goods are either addressed to or intended for the recipient, they shall be deemed a gift to the recipient who may use them or dispose of them in any manner without any obligation to the sender. ILL. Rev. STAT., ch. 121 1/2, § 351 (Supp. 1970).

64. WASH. Rev. CODE ANN. § 19.57 .020 (Supp. 1969).

65. MD. Ann. Code art. 83, § $21 A^{\prime}(1969)$.

66. Minn. Stats. Ann., § 325.92 (Supp. 1970); Tenn. Code Ann. § 47-15-114 (Supp. 1969). Ohio has an unconditional gift statute that does not have the "unless otherwise agreed" restriction. OHIo Rev. Code ANN. § I333.60 (Supp. 1969). 
Except for the Washington statute's restricted applicability-mailed goods only -all the "gift" statutes at least appear to protect recipients of all unordered merchandise from legal liability. ${ }^{87}$ Actions to collect for unsolicited goods, however, are rare, perhaps because many recipients still believe that they have a legal obligation and pay for the unwanted goods. Even if they are aware of the law, they may suffer the inconvenience of receiving unwanted goods and subsequent demands for payment. As long as enough people make the practice profitable by paying for such goods, the problem will continue. Because these statutes protect only the informed recipient, their success is completely dependent upon consumer legal education. While an informed public is ideal, legislation should aid "that vast multitude which includes the ignorant, the unthinking, and the credulous" 88 as well as the informed.

The new California statute ${ }^{69}$ and the statutes of New York, ${ }^{70}$ Connecticut, ${ }^{71}$ Hawaii, ${ }^{72}$ Michigan, ${ }^{73}$ and West Virginia ${ }^{74}$ attack the problem directly by prohibiting the sending of unsolicited goods and declaring them unconditional gifts. ${ }^{75}$ By expressly prohibiting the practice, these acts, coupled with injunctive power in public prosecutors, offer an effective vehicle for public enforcement without relying on the vagaries of individual consumer responses. Since only one person is necessary to inform the public prosecutor of a violation, the potential for halting the practice is great, assuming the violator is a resident of the state wherein the injunction is sought. ${ }^{78}$ Injunctive

67. The "complete defense" provided by the Maryland and Washington statutes may be somewhat illusory in that the wording suggests that to take advantage of the "defense" the recipient must establish that the goods were sent voluntarily, and that he did not order them. Since the evidence for both of these facts is primarily in the sender's control he should have the burden of proof. In contrast, those statutes declaring the merchandise an unconditional gift negate all the sender's claims.

68. Aronberg v. FTC, 132 F. 2d 165, 167 (7th Cir. 1942).

69. Cal. Civil Code $\S 1584.5$ (West Supp. 1970).

70. N.Y. Gen. Bus.'LAW $§ 396$ (McKinney Supp. 1969-70).

71. Conn. Gen.Stat. AnN. § 42-133a (Supp. 1970-71).

72. Hawall Rev. Laws § 481B-1 (Supp. 1969).

73. Mich. Stat. AnN. $\$ 19.416(51)$ (Supp. 1970).

74. W. VA. CODE ANN. § 47-11A-12a (Supp. 1970).

75. These statutes are typically worded as follows:

No person . . . or corporation . . . in any manner . . . shall offer for sale goods where the offer includes the voluntary and unsolicited sending of goods by mail or otherwise not actually ordered or requested by the recipient, either orally or in writing. The receipt of any such unsolicited goods shall be deemed for all purposes an unconditional gift to the recipient. . . Mich. Stat. ANn. \$19.416(51) (Supp. 1970).

76. A non-resident corporation doing only a mail-order business might be susceptible to an in 
power, crucial to eliminating this sales technique, should be made available to county prosecutors and individual citizens, as well as the state attorney generals. ${ }^{77}$ The New York statute authorizes the attorney general to seek injunctive relief against violators without proof that someone has been "misled, ... deceived or otherwise damaged ...."78 Use of unsolicited goods as a sales technique might be further inhibited and injured persons compensated if a class action for punitive damages, court costs, and attorneys' fees were allowed as a complementary remedy.

Failure of the state statutes to define the term "unsolicited goods" may lead to a serious overinclusion problem, especially where the statutes designate such goods as unconditional gifts. "Unsolicited goods" might include goods sent after an order has been cancelled, the wrong goods, or merchandise sent to the wrong person. The mistaken seller, unless he has adopted a practice which fosters mistakes, ${ }^{79}$ would not be engaging in the type of abusive practice the

personam action in state courts where unsolicited goods are sent, but the impotence of an injunction against such activity suggests that private actions for money damages are a better remedy against foreign corporations. See F. James, Civil Procedure $\$ \S 12.8,12.10$, at 64748 (1965), for a discussion of the jurisdiction issues. Compare Huntington v. Attrill, 146 U.S. 657 (1892) with Wisconsin v. Pelican Ins. Co., 127 U.S. 265 (1888) and Union Pac. R.R. v. Rule, 155 Minn. 302, 193 N.W. 161 (1923); Buswell v. Buswell, 377 Pa. 487, 105 A.2d 608 (1954); Bailey v. Tully, 242 Wisc. 226, 7 N.W.2d 837 (1943), for an indication of the ineffectiveness of an injunction against non-resident corporations.

77. In California the recipient may enjoin the practice and may be awarded punitive damages and costs. The California statute provides in part:

If after any such receipt ... the sender continues to send bill statements or requests for payment with respect thereto an action may be brought by the recipient to enjoin such conduct in which action there may also be judgment for exemplary damages and costs incurred by the recipient. CAL. CIvIL CODE $\S 1584.5$ (West Supp. 1970).

78. The New York statute provides in part:

(3) Whenever there shall be a violation of this section, an application may be made by the attorney general in the name of the people of the state of New York to a court or justice having jurisdiction to issue an injunction and upon notice to the defendant of not less than five days, to enjoin and restrain the continuance of such violation; and if it thall appear to the satisfaction of the court or justice that the defendant is, in fact, violating this section, an injunction may be issued by such court or justice, enjoining and restraining such aetion or violation, without requiring proof that any person has, in fact, been misled or deceived or otherwise damaged thereby. N.Y. GEN. Bus. LAw $\$ 396$ (McKinney 1968).

79. An example of a practice which encourages mistakes is the sending of goods on the basis of coupons contained in advertisements without requiring prepayment or confirmation. It is arguable such mistakes are not bona fide. Cf. United States v. Vitasafe Corp., 1964 Trade Cas. I 71,231 (S.D.N.Y. 1964). The FTC, however, has recognized this form of mistake as a defense. E.g., United States Stationery Co., 49 F.T.C. 745, 751 (1953); United States Pencil Co., 49 F.T.C. 734, 742-43 (1953). 
statutes were designed to eliminate. Recipients of goods sent by mistake will usually be aware of the mistake because of nonconforming goods, improper address, or failure to request payment. As long as the sender can provc that the mistake was bona fide, such goods should be excluded from the definition of "unsolicited." ${ }^{80}$ Any recovery permitted for goods sent by mistake should be limited to the amount of recipient enrichment.

The New York and California statutes prohibiting outright the sending of unsolicited merchandise and providing injunctive enforcement power, are clearly superior to the other state statutes. Initial reports indicate that unsolicited goods complaints concerning domestic concerns have almost disappeared in New York since the statute's enactment. ${ }^{81}$ The other statutes ${ }^{82}$ provide a legal basis for what many recipients already do-dispose of the goods-but will not stop the payment demands. Threats to ruin one's credit are not idle in a society dependent upon credit. Although all state remedies are confined by territorial limitations, ${ }^{83}$ they can effectively control intrastate unsolicited merchandise traffic. ${ }^{84}$ But elimination of interstate operations requires federal action.

80. The New York and Washington statutes may exclude goods sent by mistake by limiting the defense to goods sent "voluntarily." See notes 70 \& 64 supra. The Indiana act only covers "merchandise . . . delivered to the person for whom it was intended." IND. ANN. STAT. § 51801. (Supp. 1969). Finally, the Uniform Commercial Code provides that when the wrong goods are delivered to a person who has entered into an agreement, the recipient must hold the goods, return them, or resell them for the buyer's account. UCC $\$ \S 2-602(2), 2-603,2-604$.

81. Letter from Barnett Levy, Assistant Attorney General in Charge, Consumer Frauds and Protection Bureau, New York State, to the Duke Law Journal, Nov. 30, 1970. The success of the New York statute ean no doubt be attributed in large part to the publicity given the new statute by the Attorney General through articles in local newspapers across the state.

82. See notes 71-74 supra.

83. See note 76 supa and accompanying text.

84. The following is suggested as a model state statute:

1. The legislature finds that the practice of sendiag goods of all sorts and performing services when sueh goods or services have not been ordered, solicited, or authorized by the recipient constitutes a misleading and deceptive practice detrimental to the economy of the state, the principles of fair competition, and to the general welfare of the people of this state. It is the purpose of this statute to prohibit this practice and to protect recipients of such goods and services.

2(a). Unless trade usage indicates otherwise, the term "unsolicited goods and services" as used in this statute sball include but not be limited to goods, wares, merchandise, periodicals, services, or other article, product, or item of trade which is voluntarily sent or performed by any means to or for any person without an actual order, request, or authorization from the recipient, either orally or in writing, as a means of selling, renting, or leasing said goods, wares, merchandise, periodicals, services, or other article, product, or item of trade, provided that goods sent or services performed by mistake shall not be included within the term "unsolicited 


\section{FEDERAL REMEDIES}

\section{Federal Trade Commission}

The FTC has been delegated the task of preventing "unfair methods of competition in commerce, and unfair and deceptive acts or practices in commerce." 85 So long as the commerce requirement is fulfilled ${ }^{88}$ and action by the FTC would be in the public interest, ${ }^{87}$ the

goods and services" if the sender proves that the goods or services were sent or performed because of a bona fide mistake.

2(b). The term "person" as used in this statute shall mean any individual, firm, partnership, corporation, association, business, charitable organization, or agent or employee thereof.

3. No person shall in any manner or by any means send unsolicited goods, or perform unsolicited services, as a means of offering such goods and services for sale, rent, or lease.

4. Unsolicited goods and services are hereby deemed to be a gift, and the recipient has the right to use or dispose of unsolicited goods and services in any way without any obligation to the sender, or to refuse to accept delivery or performance of unsolicited goods and services. Notwithstanding the failure to pay for or return unsolicited goods to the sender, in any action by the sender for the priee, value, or return of goods, or for the price or value of services, the sender shall have the burden of proving that the goods or services delivered or performed were not unsolicited goods and services.

5(a). In addition to all remedies, actions or defenses authorized in this statute, whenever there shall be a violation of this section, an applieation may be made by any county prosecuting attorney, or the attorney general, in the name of the people of this state, or by any person to a court or justice having jurisdiction to issue an injunction, and upon notice to the defendant of not less than seven days, to enjoin and restrain the continuance of such violation; and if it shall appear to the satisfaction of the court or justice that the defendant is, in fact, violating this section, an injunction may be issued by such court or justiee, enjoining and restraining such action or violation, without requiring proof that any person has, in fact, been misled or deceived or otherwise damaged thereby.

5(b). Any person who obtains an injunction under this statute shall recover court costs and reasonable attorneys' fees.

5(c). Any person, either individually or in a class action, who has paid for unsolicitedgoods may recover in a civil suit brought within three years after payment is made twiee the amount paid plus interest at a rate of 8 pereent from the time of payment, court costs, and reasonable attorneys' fces.

85. 15 U.S.C. $\S 45$ (1964). False advertising is dealt with specifically in id. $\S \S 52-55(\mathrm{a})$.

86. Jurisdiction of the FTC requires more than acts which merely affect interstate commerce, FTC v. Bunte Bros., 312 U.S. 349 (1941), but the Commission has asserted jurisdiction over intrastate acts that are a part of a broader program of interstate activity, e.g., Bankers Sec. Corp. v. FTC, 297 F.2d 403 (3d Cir. 1961), affg 57 F.T.C. 1219 (1960). The furthest extension, to date, of the FTC's jurisdiction has been based on the interstate distribution of newspapers containing advertisements for the defendant or his product. E.g., S. Klein Dep't Stores, Inc., 60 F.T.C. 388 (1962) (dismissed); Peerless Camera Stores Corp., [1963-65 Transfer Binder] Trade REG. REP. I 16,649 (FTC 1963). Since most unsolicited goods are sent by mail, this might provide the jurisdictional requirement. Apparently, however, use of the mails has never been relied upon. But cf. Guziak v. FTC, 361 F.2d 700, 704 (8th Cir. 1966), cert. denied, 385 U.S. 1007 (1967). See generally G. Alexander, Honesty ANd Competition 14-17 (1967); Developments in the Law-Deceptive Advertising, 80 HARv. L. REv. 1008 (1967).

87. To act, the Commission must find "that a proceding by it in respect thereof would be to 
Commission has broad discretion in fashioning remedies. Through a cease and desist order it may prohibit either an entire method of selling or one aspect of a sales technique, condition further sales, or require an affirmative disclosure in communications with customers. ${ }^{8 \mathrm{~g}}$

Action under the Federal Trade Commission Act requires no proof of fraud ${ }^{89}$ or actual deception; tendency or capacity to deceive is sufficient. ${ }^{90}$ The literal truth is not a defense ${ }^{91}$ since the general public's understanding controls. In measuring the capacity of an advertisement to deceive, the FTC looks to the understanding of the general public and not that of the expert..$^{22}$ The defendant's knowledge of the falsehood is as immaterial as his intent to deceive. ${ }^{93}$

Federal Trade Commission concern over unsolicited sales dates from at least 1939.94 The Commission's present position is contained in Consumer Bulletin No. 2,95 which summarizes two recent FTC

the interest of the public." 15 U.S.C. $\$$ 45(b) (1964). An FTC finding of public interest will usually be accepted by the courts. E.g. Montgomery Ward \& Co. v. FTC, 379 F.2d 666, 672 (7th Cir. 1967); Exposition Press, Inc. v. FTC, 295 F.2d 869 (2d Cir. 1961), cert. denied, 370 U.S. 917 (1962); Bear Mill Mfg. Co. v. FTC, 98 F.2d 67 (2d Cir. 1938); see G. Al.eXANDER, supra note 86 , at $14-17$.

88. E.g., Atlantic Ref. Co. v. FTC, 381 U.S. 357, $372-73$ (1965) (entire method prohibited); S. \& S. Pharm. Co. v. FTC, 408 F.2d 487, 489 (5th Cir. 1969) (condition further sales); Portwood v. FTC, 418 F.2d 419, 424 (10th Cir. 1969) (affirmative disclosures). See 15 U.S.C. $\S 45(b)$ (1964).

89. FTC v. Algoma Lumber Co., 291 U.S. 67,81 (1934); D.D.D. Corp.v. FTC, 125 F.2d 679 (7th Cir. 1942).

90. FTC v. Algoma Lumber Co., 291 U.S. 67, 81 (1934); S. Buchsbaum \& Co. v. FTC, 160 F.2d 121 (7th Cir. 1947); Charles of the Ritz Distrib. Corp. v. FTC, 143 F.2d 76 (2d Cir. 1944).

91. Kalwajtys v. FTC, 237 F.2d 654 (7th Cir. 1956), cert. denied, 352 U.S. 1025 (1957); Aronberg v. FTC, 132 F.2d 165 (7th Cir. 1942).

92. FTC v. Standard Educ. Soc'y, 302 U.S. 112 (1937); Book-of-the-Month Club, Inc. v. FTC, 202 F.2d 486 (2d Cir.), cert. denied, 346 U.S. 883 (1953); Aronberg v. FTC, 132 F.2d 165 (7th Cir. 1942).

93. Bockenstette v. FTC, 134 F.2d 369 (10th Cir. 1943); D.D.D. Corp. v. FTC, 125 F.2d 679 (7th Cir. 1942).

94. E.g., Mystic Stamp Co., 28 F.T.C. 1796 (1939). The Commission's interest has continued. Joseph L. Portwood [1967-70 Transfer Binder] TRADE REG. REP. II 18,176 (FTC 1968); S \& S Pharm. Co., 3 TRADE REG. REP. I 18,086 (Oct. 9, 1967), affd per curiam, 408 F.2d 487 (5th Cir. 1969); Independent Directory Corp. v. FTC, 188 F.2d 468 (2d Cir. 1951); Dorfman v. FTC, 144 F.2d 737 (8th Cir. 1944); Imperial Sales Co., 3 TRADE ReG. ReP. I 18,574 (FTC 1968); K \& S Pharm. Co., 3 TRADE Reg. ReP. I 18,113 (FTC 1968); 1895 Assocs., Inc., [1965-67 Transfer Binder] TRADE Reg. ReP. If 17,319 (FTC 1965); Betty Phillips, Inc., 51 F.T.C. 1433 (1954); National Educ., Ine., 49 F.T.C. 1358 (1953); United States Stationery Co., 49 F.T.C. 745 (1953); United States Pencil Co., 49 F.T.C. 734 (1953); House of Plate, Inc., 47 F.T.C. 1411 (1951); Norman Co., 40 F.T.C. 296 (1945); Interstate Home Equip. Co., 40 F.T.C. 260 (1945); MysticStamp Co., 28 F.T.C. 1796 (1939).

95. "Unordered Merchandise-Shipper's Obligations and Consumers' Rights," (June 25, 1968), 2 Trade Reg. REP. If 7,559.75 (1969). The Commission's present position in the 
cases involving unsolicited goods and concludes with the following statement:

Absent a prior agreement between the parties, any shipment of unordered merchandise, and any communication designed to obtain payment for, or return of, such merchandise, must be accompanied by a clear and conspicuous disclosure that the merchandise has been sent to the recipient unsolicited, that the recipient is under no obligation either to return the merchandise to the sender or to preserve it intact, and that the recipient is required to pay for the merchandise only if he uses.it or decides to purchase it.

This disclosure provision does not accurately represent either the common law or existing state statutes. In implying that the recipient is under no duty to preserve the goods intact, the statement conflicts with the contract cases holding that any dealing with the goods inconsistent with the sender's title will make the recipient liable for the price or value of the goods..$^{97}$ Moreover, the bailment cases hold that an involuntary bailee at least has a duty not to dispose of the goods..$^{98}$ The bulletin also conflicts with the cases holding the recipient liable for the price when he gives the goods to another ${ }^{99}$ and witl the state gift statutes. ${ }^{100}$ The FTC position may cause persons living in states with new statutes to pay for some goods for which they are not obligated and persons in other states to deal with the goods in a way that will make them liable. ${ }^{101}$ By failing to reflect the law accurately the Bulletin may actually promote unsolicited sales rather than prevent them.

The two cases discussed in the Consumer Bulletin exemplify the FTC's handling of unsolicited goods cases. In one case a distributor

analogous area of door-to-door sales is represented in a proposed rule providing a consumer three days to eancel a door-to-door sale and requiring the seller to follow certain stringent rules, including furnishing a cancellation form for the purchaser at the time of the sale, the inserting of a "clear and conspicuous" statement within the sales contract that the seller agrees to arbitrate any dispute and to submit to the jurisdiction of the purchaser's residence, and waiting five days before transferring a buyer's note to a finance company or any third party. The FTC will hold a public hearing on the proposed rule in January, 1971. FTC Proposed 3-Day Cooling-Off Period For Door-to-Door Sales, FTC Press Release (Sept. 30, 1970).

96. 2 Trade REg. ReP. If 7,559.75 (1969) (emphasis added).

97. See notes 25-29 supra and accompanying text.

98. See notes $49-54$ supra and accompanying text.

99. See note 41 supra.

100. See notes 63-65 supra and accompanying text. However, the Bulletin disclosure may be in accord with the Virginia statute, notes 58-59 supra.

101. See North Carolina Consumers Council, Inc., Newsletter, Vol. 1, No. 1, Sept. 1968, which advises readers they are free, beeause of the FTC bulletin, to throw away unsolicited goods. 
of patent medicine simultaneously sent unordered merchandise to druggists and advertised in trade newspapers that the merchandise was available at their stores. ${ }^{102}$ The merchandise was accompanied by an invoice, sample advertisement, and form letter. The Commission found that this practice "is an inherently unfair method of competition which 'pushes' a misinformed retailer into becoming an unwilling buyer or agent" ${ }^{103}$ and issued a cease and desist order prohibiting the seller from sending merchandise to any retailer without the written consent of the recipient. ${ }^{104}$

In the Portwood case the proprietors of a stamp business mailed unordered stamps on approval to $120-150$ persons each week. ${ }^{105} 1$ the stamps were not purchased or returned in thirty days, a series of form letters would follow. The first two were "reminders," the third referred to "an understanding" that the stamps would be paid for or returned promptly, ${ }^{106}$ and the final one-the fifth or sixth sent-threatened to transfer the "account" to an attorney for action. No accounts were ever referred to an attorney, and the sender ultimately abandoned the stamps if payment was not made. ${ }^{107}$ Personal letters were sometimes sent, and in a few cases recipients were threatened with liability for "stolen" stamps. ${ }^{108}$ About eighty percent of the recipients either paid for the stamps or returned them after receiving only the stamps, the accompanying "Approval Invoice," and a self-addressed, stamped evelope. An additional ten percent responded after the first two notices. ${ }^{103}$

The hearing examiner found that the senders had violated section 5 of the Federal Trade Commission Act ${ }^{110}$ by making false or misleading statements to recipients who had not previously dealt with

102. S \& S Pharm. Co., [1967-70 Transfer Binder] 3 Trade Reg. ReP. I 18,086 (FTC 1967), affd per curiam, 408 F.2d 487 (5th Cir. 1969). The advertisement also stated that the druggist guaranteed the product.

103. Id. at 20,536 .

104. 408 F.2d at 489.

105. An average approval book was priced at $\$ 6.95$, but a few ranged as high as $\$ 250$. The average sale was \$3. Portwood v. F.T.C., 418 F.2d 419 (10th Cir. 1969).

106. This notice, sent about thrce months after the stamps, was the first suggestion that the stamps could be returned rather than purchased. The word "understanding" was changed to "expectation" before the FTC Examiner's hearing. Id. at 420.

107. Joseph L. Portwood, [1967-70 Transfer Binder] Trade Reg. ReP. I] 18,176 at 20,590 (FTC 1968).

108. Id. at 20,857 .

109. 418 F.2d at 421 .

110. IS U.S.C. \$ 45(a)(1) (1964). 
the sender or who had requested that no further stamps be sent. ${ }^{11} \mathrm{He}$ ordered the senders to cease and desist from making the misleading representations, to stop sending stamps to recipients who had requested that no more stamps be sent, and to include with any communications sent in connection with unordered goods a statement that "the recipient is under no obligation to initiate the return of such merchandise and that, unless the recipient uses such merchandise, the recipient is under no obligation to pay for such merchandise." "12

On appeal the Commission endorsed the order with two modifications. First, it expanded the order's application to all recipients, not simply those who had either not made previous orders or had requested that no additional unordered goods be sent. Second, the affirmative disclosure requirement was expanded to include the following:

(a) that the merchandise is being sent to the recipient unsolicited,

(b) that the recipient is under no obligation either to return the merchandise

to the sender, or to preserve it intact, and,

(c) that he is required to pay for the merchandise only if he decides to purchase it." ${ }^{13}$

Although the FTC found explicit misrepresentations, it was particularly concerned with the implicit misrepresentations in statements such as "please return this invoice with your payment."114 Because of such implicitly false statements and the confusion surrounding the recipient's legal obligations, the Commission found that "deception inheres in the very act of attempting to persuade [sender's] mailees to purchase the merchandise." 115 It therefore concluded that the only remedy which would offset the deception and protect the public would be an affirmative disclosure informing recipients of their obligations with respect to the goods.

In response to the senders' argument that the required disclosure was contrary to common law, the FTC contended that the disclosure

111. Joseph L. Portwood, No. 8681 at 18 (F.T.C. Oct. 17, 1966) (Hearing Examiner opinion). The examiner considered that the deception resulted from an implied obligation to purchase or return the stamps, allegations of recipient mail fraud liability, and the threats to transfer the aecounts to an attorney.

112. Id. at 35 .

113. Joseph L. Portwood, [1967-70 Transfer Binder] Trade Reg. Rep. If 18,176 at 20,585 (FTC 1968).

114. Id. at 20,589 .

115. Id. at 20,590 . 
was "wholly accurate" contract and bailment law were inapplicable. ${ }^{117}$ The senders, by failing to invoke the common law to enforce payment,

-by their own conduct [made] it clear that whatever the principles of law may be relative to express and implied contract or to the rights of bailees and the like, they do not operate the type of business to which these principles might possibly be applicable. ${ }^{118}$

The Court of Appeals for the Tenth Circuit required two changes in the FTC's order. To make the required disclosure conform with state statutory and common law, subparagraphs (b) and (c) were modified to read as follows:

(b) that the recipient is not obligated to return the merchandise, and

(c) that he is required to pay for the merchandise only if he decides to purchase it or uses it, and not then if the law of the recipient's State permits him to use unsolicited merchandise without payment. ${ }^{\text {"I }}$

Otherwise, the court endorsed the Commission's affirmative disclosure requircment as a remedy reasonably related to the unlawful practices $^{120}$ and found the prohibition against sending stamps to unwilling recipients to be within the discretion of the Commission. As thus modified, the court held that the order should be enforced.

The disclosure requirement, as modified, conforms more closely to the case law and new statutes by recognizing that the recipient may be

116. Id. at 20,591. The Commission found no support for the proposition that a recipient may be liable to pay for unsolicited goods if he does anything other than use them. See cases cited in notes $26-29$ supra.

117. Id. at 20,590. The Commission stated that because of the recipient's ignorance of the law it would be "particularly reprehensible" for the sender to attempt to enforce contract or bailment principles. Id.

118. Id. The Commission used a similar argument in disposing of the senders' contention that because of prior dealings some recipients had an obligation to return the goods. The FTC's reply was that the prior dealings were irrclevant because in communicating with recipients, the sender sent the same letters to everyone. Id. at 20,588-89.

119. 418 F.2d at 423. The Consumer Bulletin states that a recipient "is required to pay for the merchandise only if he uses it or decides to purchase it." See note 102 supra and accompanying text. The Bulletin was issued six months after the Commission's decision in Portwood, which stated that the buyer was liable only if he wished to purchase the goods, and may represent a modifieation of the Portwood disclosure. Since the Bulletin disclosure was less reflcetivc of present law and described Portwood as an example of the FTC's current attitude, a more likely explanation is that the FTC was unaware of the conflict.

120. The power of the FTC to require an affirmative disclosure is well established. See, e.g., FTC v. Colgate-Palmohive Co., 380 U.S. 374, 390 (1965); J.B. Williams Co. v. FTC, 381 F.2d 884, 888 (6th Cir. 1967); Ward Laboratories, Inc. v. FTC, 276 F.2d 952, 955 (2d Cir. 1960), cert. denied, 364 U.S. 827 (1964); L. Heller \& Son v. FTC, 191 F.2d 954 (7th Cir. 1951); Dorfman v. FTC, 144 F 2d 737, 739 (8th Cir. 1944). 
obligated if he uses the goods ${ }^{121}$ and acknowledging the existence of state laws deeming such goods to be gifts. ${ }^{122}$ However, it leaves the most bothersome question unanswered: does the consumer have to preserve the unsolicited goods?

An accurate and informative disclosure statement would eliminate the deception for consumers who could and would read the disclosure. ${ }^{123}$ Use of the disclosure statement tests the economic utility of this form of selling, assuring survival only if the number of consumers actually desiring the goods is substantial. Finally, a disclosure statement logically complements the new state statutes by informing consumers that such statutes exist. But an affirmative disclosure is not the ideal solution. It does not relieve the recipient of the nuisance of having to do something with the goods and preserves some anti-competitive characteristics. ${ }^{124} \mathrm{~A}$ better remedy is offered through the postal system.

\section{Postal Remedies Prior to the Postal Reorganization Act}

Since the mails are often used for the delivery of unsolicited merchandise, the Post Office is a logical source of effective regulation. Postal regulations authorize an addressee to refuse certain mail before

121. See note 25 supra and accompanying text.

122. See notes 63-66 supra and accompanying text.

123. An accurate disclosure statement necessarily differentiates between states with laws dealing with unsolicited goods and states without such laws. A seller could use different statements for different states or he could include all of the information in one statement.

For states with "unconditional gift" statutes, see note 66 supra and accompanying text; an accurate statement would be:

This merchandise is being sent as an unconditional gift and not as an offer of sale. You may keep it without obligation to pay for the goods.

For other states with conditional gift statutes, see note 66 supra and accompanying text, an accurate statement could read as follows:

This merchandise is being sent unsolicited. It is a gift and you are free to use it without obligation; you have no obligation to pay for it, return it, or preserve it. You may pay for the merchandise if you decide to purchase it.

For goods sent to Virginia, see notes 58-59 supra and aecompanying text:

This merchandise is being sent unsolicited and you are obligated to pay for it only if you use it or decide to purchase it. You have no obligation to return the merchandise or preserve it intact.

For goods sent to other states:

This merchandise is being sent unsolicited. You do not have to pay for it unless you decide to purchase it, use it, destroy it, or give it away. You have no obligation to return the merchandise but must hold it for us for at least one month to allow us to reclaim the goods.

124. See notes 14, 16 supra and accompanying text. 
or after delivery if unopened. ${ }^{125}$ In 1967 Congress exercised its postal powers to prohibit the mailing of matter resembling bills, invoices, or statements of account which could induce payment where no obligation existed, unless the absence of a binding commitment was clearly indicated. ${ }^{126}$ The significance of the statute, which is similar to the 1967 California act, ${ }^{127}$ is minimized by the fact that such deception was already illegal under existing postal laws if specific intent to deceive could be established. ${ }^{128}$

The principal statutory weapon available prior to the Postal Reorganization Act $^{129}$ was the civil postal fraud statute ${ }^{130}$ which

125. 39 C.F.R. $\$ 154.1$ (a) (1970). This provision does not apply to registered, insured, certified, or COD mail. The regulations prohibit the use of the COD service to send goods to persons who have not ordered them. Id. § 163.2(d)(1).

126. 39 U.S.C. $\S 3001$ (d) (Supp. V, 1970).

(c) Matter otherwise legally aeceptable in the mails which-

(I) is in the form of, and reasonably could be interpreted or construed as, a bill, invoicc or statement of account due; but

(2) constitutes, in fact, a solicitation for the order by the addressee of goods or services, or both; is nonmailable matter, shall not be carried or delivered by mail, and shall be disposed of as the Postmaster General directs, unless such matter bears on its face, in conspicuous and legible type in contrast by typography, layout, or color with other printing on its face, in accordance with regulations which the Postmaster General shall prescribe-

(A) the following notice: "This is a solicitation for the order of goods and/or services and not a bill, invoice, or statement of account due. You are not under obligation to make any payments on account of this offer unless you accept this offer"; or

(B) in lieu thereof, a notice to the same effect in words which the Postmaster General may prescribe.

The regulations issued by the Postmaster General under this statute were published in 33 Fed. Reg. 4512 (March 14, 1968).

127. Sce note 60 supra.

128. "There can be no doubt that a scheme which contemplates the sending of bills through the mails to persons not indebted to the sender, and for the purpose of inducing them to part with money they do not owe, is a fraudulent scheme." Bronzin v. United States, 309 F.2d 158, 159 (8th Cir. 1962). This case involved a conviction for criminal mail fraud under 18 U.S.C. $\$ 1341$ (1964), for attempting to collect money for advertisements placed in newspapers without authorization. For other cases involving convictions for criminal mail fraud for attempting to collect money not owing, see Lesselyoung v. United States, 18 F.2d 472 (8th Cir.), cert. denied, 275 U.S. 535 (1927); Hughes v. United States, 231 F. 50 (5th Cir.), cert. denied, 242 U.S. 640 (1916); Weeber v. United States, 62 F. 740 (C.C. Colo. 1894). For a statement of the civil fraud statute, see note 130 infra.

129. See notes $138-47$ infra and accompanying text.

130. 39 U.S.C. $\$ 3005$ (Supp. V, 1970). The statute provides in part:

(a) Upon evidence satisfactory to the Postmaster General that any person is engaged in conducting a scheme or device for obtaining money or property through the mail by means of false representations . . the Postmaster General may issue an order which-

(1) directs any postmaster at an office at which registered or certified letters or other letters or mail arrive, addressed to such a person or his representative, to return such 
prohibits the use of the mails to further a scheme for obtaining money or property through false representations. That statute enables the Postmaster General, after a hearing ${ }^{131}$ establishing the requisite fraudulent scheme, to treat all mail related to the scheme as "fraudulent" and return it to the sender. ${ }^{132}$ Although application of the statute requires proof of a specific intent to deceive, ${ }^{133}$ such intent may be inferred from a reckless disregard of the truth. ${ }^{134}$ The necessary misrepresentation may stem from statements artfully disguised to mislead. ${ }^{135}$ As long as the intent to defraud and the use of the mails in furtherance of the scheme are established, it is not necessary to prove that anyone was defrauded or that any complaints were received. ${ }^{136}$ In a 1968 amendment Congress eliminated the requirement of a specific intent to deceive. ${ }^{137}$

letters or mail to the sender appropriately marked as in violation of this section, if such person, or his representative, is first notified and given reasonable opportunity to be present at the receiving post office to survey such letters or mail before the postmaster returns sueh letters or mail to the sender . . . .

The Criminal Mail Fraud Statute is found at 18 U.S.C. \$ 1341 (1964). For a concise statement of the different purposes of the two postal fraud statutes, see Commissioner v. Heininger, 320 U.S. 467,474 (1943).

131. The procedures for the hearing before the Postmaster are found at 39 C.F.R. § 952.I$.33(1970)$.

132. Upon a showing of probable cause, the Postmaster General may secure a preliminary injunction from a district court in order to detain the defendant's incoming mail pending conclusion of the fraud hearing and any appeal therefrom. 39 U.S.C. \$ 4007 (1964). In Reilly v. Pinkus, 338 U.S. 269, 277 (1949), the Supreme Court expressed concern with "the severity of a mail fraud order which could wholly destroy a business" by preventing an offender from using the mails. A 1968 amendment, 39 U.S.C. $\$ 3005(a)(1)$ (Supp. V, 1970), provides that the violator may inspeet the mail before it is returned by the Postmaster-insuring that only mail relating to the scheme is returned, thereby legislating current postal practice and following available case precedent. Compare Tourlanes Publishing Co. v. Summerfield, 231 F.2d 773 (D.C. Cir.), cert. denied, 352 U.S. 912 (1956), with Parker v. Summerfield, 265 F.2d 960 (D.C. Cir. 1959). See 1968 U.S. Code Cong. \& AD. News 4290-91.

133. Reilly v. Pinkus, 338 U.S. 269,277 (1949).

134. Parker v. Summerfield, 265 F.2d 359 (D.C. Cir. 1959).

135. Donaldson v. Read Magazine, 333 U.S. 178 (1948).

136. Farley v. Heininger, 105 F.2d 79 (D.C. Cir.), cert. denied, 308 U.S. 587 (1939).

137. 39 U.S.C. $\$ 3005$ (Supp. V, 1970); The Attorney General of the United States suggested in a letter to the Chairman of the House Post Office and Civil Service Committee that the proposed amendment might be held unconstitutional because of the Supreme Court's coneern with the severity of stopping all mail sent to a violator and interest in requiring an actual fraud test. H.R. REP. No. 235, 90th Cong., 2d Sess. 10-11 (1967). The phrase "false or fraudulent . . . representations" was changed to "false representations," thereby preventing a court from ignoring the conjunction. See Letter from the Postmaster General to Chairman of House Post Offiee and Civil Service Committee, id. at 9. The Court had previously interpreted "false or fraudulent" as equivalent to "fraudulent." Reilly v. Pinkus, 338 U.S. 269 (1949); Seven Cases v. United States; 239 U.S. 510,517 (1916). 
Since many unsolicited merchandise deliveries at least imply that the recipient owes money, the transfer of unsolicited goods per se may now violate the act. Where the sender includes a bill or uses a collection agency, sueh explicit misrepresentation clearly violates the civil fraud statute. Because most senders use the mails, the civil fraud statute could be an effective means of either abolishing unsolicited selling or forcing senders to eliminate their deception. ${ }^{138}$

\section{The Postal Reorganization Act}

The Postal Reorganization $\mathrm{Act}^{139}$ regulates unordered merchandise sent by mail through a provision resembling in part the state gift statutes. ${ }^{140} \mathrm{~A}$ recipient may treat unordered goods received in the mail as gifts and "retain, use, discard, or dispose of . . . [the goods] . . . without any obligation to the sender . . ." " The Act further deems the practice of mailing unsolicited merchandise and the mailing of a bill or any "dunning" communication related thereto an unfair method of competition in violation of section 5 of the Federal

138. In the case of periodicals, another regulatory possibility is the rejection or revocation of second class mailing privileges. See 39 U.S.C. $\$ \S 4351-70$ (1964). This sanction would amount to a removal of a subsidy to the mailers of unsolicited periodicals. Application, however, appears remote unless there were so many issues sent to non-subscribers that the periodical was "designed primarily for advertising purposes or for free circulation." Id. $\$ 4354(\mathrm{c})$. See Ablard \& Harrison, The Post Office and the Publishers' Pursestrings:A Study of the Second-Class Mailing Permit, 30 Geo. WASh. L. REv. 567, $581-88$ (1962).

139. Postal Reorganization Act, Pub. L. No.91-375 (Aug. 12, 1970).

140. See notes 63-65 supra and accompanying text. The text of the statute is as follows:

(a) Except for (1) free samples clearly and conspicuously marked as such, and (2) merchandise mailed by a charitable organization soliciting contributions, the mailing of unordered merchandise or of communications prohibited by subsection (c) of this section constitutes an unfair method of competition and an unfair trade practice in violation of section 45(a)(1) of title 15 .

(b) Any merchandise mailed in violation of subsection (a) of this section, or within the exceptions contained therein, may be treated as a gift by the recipient, who shall have the right to retain, use, discard, or dispose of in any manner he sees fit without any obligation whatever to the sender. All such merchandise shall have attached to it a clear and conspicuous statement informing the recipient that he may treat the merchandise as a gift to him and has the right to retain, use, discard, or dispose of it in any manner he sees fit without any obligation whatsoever to the sender.

(c) No mailer of any merchandise mailed in violation of subsection (a) of this section, or within the exceptions contained therein, shall mail to the reeipient of any such merchandise a bill for such merchandise or any dunning communieations.

(d) For the purposes of this section, "unordered merchandise" means merchandise mailed without the prior expressed request or consent of the recipient. Id. $\S 3009$ (b).

141. Id. at 3009 (b). 
Trade Commission Act. ${ }^{142}$ Conspicuously marked free samples and merchandise mailed as charitable solicitations are exempted. ${ }^{143}$

Declaring the mailing of unordered merchandise an unfair method of competition per se goes substantially beyond FTC approaches and complements mail stop orders to deny the mails for unsolicited merchandise schemes. However, the statutory language is not free of ambiguity. Although one provision declares that the mailing of unordered merchandise is a violation of the FTC Act, ${ }^{144}$ a subsequent provision states that such goods must be accompanied by a statement informing the recipient that the goods are a gift and that he has no obligation to the sender concerning them ${ }^{145}$ Such affirmative duty to disclose an apparently unlawful act is unnecessary unless intended only as an interim measure before federal prosecution, or the disclosure is a mechanism for purging an unsolicited delivery of its illegality. Arguably, unordered goods plus the disclosure constitute "free samples . . . conspicuously marked as such"148 and are exempt from classification as an unfair trade practice since the disclosure informs the recipient that he may "retain, use, discard, or dispose of" 147 the goods as he so desires. If so, the statute constitutes a federal counterpart to the state gift statutes and offers less consumer protection than civil postal fraud stop orders.

\section{CONCLUSION}

The unsolicited merchandise sales technique flourished when the unwary consumer was protected solely by the common law which relied exclusively on technical contract and bailment principles and

142. Id. at $\S 3009$ (a). Section 5 of the FTC Act is at 15 U.S.C. \$ 45(a)(1) (1964). See notes 85-125 supra and accompanying text for a discussion of the FTC and the law of unfair trade practices.

143. Pub. L. No.91-375, § 3009(a) (Aug. 12, 1970).

144. Id.

145. Id. at $\S 3009(\mathrm{~b})$.

146. Id. at $\S 3009$ (a).

147. Id. at $\$ 3009$ (b). However, the FTC believes that the Postal Rcorganization Act "makes further action in this area unnecessary . . . ." It has therefore cancelled a proposed rule declaring it to be unlawful to ship unordered merchandise and authorizing the recipient to use the merchandise in any manner desired. FTC States Proposed Rule on Unordered Goods Now Unnecessary, FTC News Summary, No. 25 (Oct. 1, 1970). The Commission's reaction apparently indicates that it does not consider section 3009 (b) to cleanse an unsolicited delivery of its illegality. Such an interpretation leaves section 3009 (b)'s disclosure provision as a temporary consumer protection device until the FTC acts. Whether the courts will interpret it in such a manner remains questionable. 
individual consumer response to control the practice. The state legislatures' initial approach was to disclaim expressly recipient liability, more specifically to describe permitted recipient action and declare the merchandise a gift if voluntarily sent. But this approach was ineffectual since most recipients remained ignorant of the law. The next step was an attempt to inform the consumer through disclosure requirements such as those in the 1967 California statute ${ }^{148}$ and Federal Trade Commission orders. ${ }^{149}$ Disclosure was not a final solution since the sales technique remained lawful and the consumer was still required to do something with the goods. In some cases the easiest course was to pay even though one might not have purchased the goods if they had not been forced upon him. A better state approach was to declare the sales technique unlawful and to back up such a declaration by injunctive relief sought by either public prosecutors or individual recipients and to stipulate that such goods were unconditional gifts. ${ }^{150}$ However, many states did not adopt such statutes, and such remedies are effective only against intrastate unsolicited sales. The FTC, through actions under the Federal Trade Commission Act, was unable to supply a federal disclosure rule consistent with both state statutory and common law. Postal stop orders under the civil fraud statute offer an effective interstate remedy for the problem, and additional postal enforcement through the Federal Trade Commission Act may be provided by the Postal Reorganization Act. However, the impact of this Act will be completely diluted if the disclosure provision cleanses illegality. Federal legislation prohibiting all commerce in unsolicited merchandise is still needed, ${ }^{151}$ particularly if imaginative merchants are able to discover economically viable alternatives to the use of the mails. Such legislation should be easily supportable under the commerce power since unsolicited sales distort the natural flow of interstate commerce. In a truly free economy consumers deserve such protection.

148. CAL. Civil Code $\S 1716$ (West Supp. 1970). See notes 60-62 supra and accompanying téxt.

149. See notes 94-124 supra and accompanying text.

150. See notes 69-78 supra and accompanying text.

151. The complete prohibition approach is presently being considered in controlling unsolicited credit cards. A recently passed Senate bill prohibits the issuance of a credit card except in response to a request or application. S. 721, 91st Cong., 2d Sess. § 2(a) (1970). See generally 116 CoNG. Rec. S. 5790-97, 5802-03 (daily ed. April 15, 1970). See also H.R. 16542, 91 st Cong., 2d Sess. (1970). 